УДК $316.2: 364$

Пелін О.В., кандидат філософських наук, доцент кафедри соиіології і соиіальної роботи ДВНЗ «Ужсгородський національний університет»

(м. Ужгород, Украӥна)

\title{
КОМБІНОВАНІ МЕТОДИ ДОСЛІДЖЕННЯ СОЦІАЛЬНИХ ПРОБЛЕМ КАРПАТСЬКОГО СВРОРЕГІОНУ
}

Викладено можливості використання комбінованих методів дослідження транскордонного співробітниитва Карпатського єврорегіону. Наводяться приклади комплексного застосування методів економікостатистичного аналізу базових сочіально-економічних показників регіональних ринків, соиіологічних та експертних опитувань, контентаналізу протоколів Зміманих міжурядових комісій.

Ключові слова: комбіновані методи, експертні опитування, контентаналіз, транскордонне співробітництво.

The report presents the possibility of using combined methods of cross-border cooperation Carpathian Euroregion. Examples of integrated application of economic and statistical analysis of basic socio-economic indicators of regional markets, sociological and expert interviews, content analysis protocols joint government commissions.

Keywords: combined methods, expert interviews, content analysis, crossborder cooperation.

Нова політична i економічна ситуація на початку 90-х років продиктувала необхідність нових підходів у міжнародних відносинах, актуалізувала нові підходи до міжрегіонального та транскордонного співробітництва. На кордонах України було створено декілька єврорегіонів, серед яких після багатьох років інтенсивних транскордонних відносин 14 лютого 1993 року був створений Карпатський єврорегіон. Від об’єднує 19 прикордонних адміністративно-територіальних одиниць, в яких проживає більше 16 млн. осіб різних національностей. Це вимагає комплексного підходу в дослідженні соціально-економічних і етнонаціональних проблем транскордонного співробітництва. Саме відсутність системного підходу до організації та дослідження єврорегіональної співпраці є однією з основних перешкод, які заважають ефективному транскордонному співробітництву [1, с.193].

Дослідженням соціально-економічних проблем прикордонних територій в Україні почали займатися у кінці 80 -х років співробітники відділення 
Інституту світової економіки і міжнародних відносин АН УССР та відділу регіональних проблем комплексного соціально-економічного розвитку Львівського відділення Інституту економіки АН УССР (м. Ужгород), а на початку 90-х - співробітники відділу соціальних проблем Карпатського регіону Інституту соціології НАН України (м. Ужгород) та співробітники Інституту суспільних наук Словацької академії наук (м. Кошице). Дослідники цих наукових закладів заклали методологічні основи інтеграції економіко-статистичних методів 3 методами прикладних соціологічних досліджень. Вперше результати експертного аналізу були доведені до поєднання 3 кількісною оцінкою, яка використовувалася як регіональний фактор концентрації зайнятості (ФКЗ) [2].

Подальші дослідження транскордонного ринку Карпатського єврорегіону довели необхідність розробки і застосування комбінаційних методів, які, на відміну від формалізованих та евристичних, краще відображають “суперечливий характер кон’юнктури транскордонного ринку, що обумовлює одночасне існування різноспрямованих тенденцій в іi розвитку" $[3$, с.133]. Це означає, що дослідження кон'юнктури транскордонного ринку поєднують методи опитування намірів споживачів та збутових агентів, методи експертних оцінок, тестування ринку разом із економіко-математичними методами розрахунків економічних показників, кореляційно-регресійного аналізу, індексного методу, аналізу рядів динаміки та екстраполяції.

Мета статті - обгрунтувати доцільність застосування комбінованих методів дослідження транскордонного співробітництва на регіональному рівні. Просування до мети припускає вирішення таких завдань: визначити суть та особливості використання комбінаційних методів дослідження; довести можливості використання комбінаційних методів у дослідженні соціальних проблем Карпатського єврорегіону.

Перш за все, необхідність використання комбінованих методів дослідження транскордонного співробітництва обумовлюється багаторівневим характером транскордонних відносин та обмеженим рівнем інформації про партнерів. Транскордонні взаємодії відбуваються одночасно на рівні загальнодержавного регулювання та міжрегіональної співпраці. Деякі питання транскордонних відносин по різному сприймаються на загальнодержавному та регіональному рівні. Співробітництво на загальнодержавному рівні спирається на міжнародні угоди, а регіональне співробітництво розвивається досить спонтанно. Його рушійною силою $є$ особисті контакти з сусідами, викликані господарськими потребами, а також співпраця в галузі культури [4].

У загальному вигляді комбіновані методи дослідження - це поєднання описових принципів та кількісних параметрів. Вони $є$ проміжними між фактографічними (формалізованими) i експертними (інтуїтивними). Найчастіше до комбінованих методів відносять колективні експертні оцінки 
та різного роду види моделювання, під час якого фактографічна і експертна інформація використовується як вхідна. До більш складних комбінованих методів дослідження відносять: управління за цілями (MBO- management by objects), тестування, експертну оцінку “метод 360”", ділову гру, комплексну оцінку праці та інші [5, с.237-238].

За думкою львівських дослідників, оцінка транскордонного співробітництва не може бути визначена прямими методами. "Як непрямі методи оцінки ефективності можна використати показники прикордонної торгівлі, взаємної зовнішньої торгівлі та інвестиційної діяльності, обсяги фінансової підтримки 3 міжнародних фондів та структур, суспільні ефекти від реалізації заходів та транскордонних проектів тощо" [6, с. 210-211]. Непрямі методи оцінки не можуть спиратися виключно на статистичні дані в силу недостатньої інформації. За допомогою комбінованих методів непрямі оцінки не тільки можливі, але i здатні підвищувати якість та репрезентативність дослідження, якої не вистачає дослідженням за допомогою винятково методів експертного опитування.

Метод вимірювання товарних потоків (Commodity Flow Survey) або (CFS) $є$ фактографічним. Інтенсивність матеріальних, інформаційних, фінансових та інших потоків $є$ об'єктом дослідження логістики. Але екстраполяція CFS на результати вимірювань за шкалою соціальних дистанцій Е. Богардуса надає дослідникам можливість прослідкувати межі міжрегіональної взаємодії та перспективи транскордонного співробітництва. У деяких випадках CFS може бути доповнений індексом людського розвитку (IЛР), який являє собою інтегральну оцінку трьох складових компонентів, що характеризують довголіття, рівень освіти і доходів населення країн світу.

Комбінований метод аналізу соціально-економічних і етнонаціональних показників дає підстави для визначення регіоноутворюючих факторів. За локальними протиріччями регіональних інтересів комбіновані методи відкривають приховану невирішеність глобальних геополітичних питань, яка проявляється через міжрегіональні протиріччя. Наприклад, деякі протиріччя українсько-румунсько-молдовських відносин може бути наслідком незбалансованого розвитку Північної та Південної Свропи, яка загрожує цілісності та безпеці всього ЄС. Наявність емпіричних індикаторів глобальних геополітичних процесів надає можливість для більш обгрунтованих оцінок традиційних транскордонних відносин та завчасних прогнозів на майбутнє [7, с.173-174].

Дослідження на рівні загальнодержавного регулювання та міжрегіональної співпраці неможливе за допомогою винятково фактографічних методів і ускладнено за допомогою методів експертного опитування. Так, процес регулювання міжнаціональних взаємин набагато простіше досліджувати за допомогою комбінованих методів.

Українська двостороння дипломатія новітньої доби розпочинається 3 Угорщини. Договір про основи добросусідства та співробітництва між 
Україною та Угорською Республікою був укладений ще 6 грудня 1991 року і набув чинності 16 червня 1993 року. Вирішення практичних питань надання такої допомоги Сторонами було покладено на Змішану комісію $[8 ; 9 ; 10]$. За цей час накопичена значна кількість протоколів міжурядових комісій. Результати контент-аналізу протоколів Змішаних міжурядових комісій свідчать про суттєве зростання уваги урядів до поширення угорської мови, питань навчання і освіти угорської меншини і мовного питання в цілому. Разом зі збільшенням рішень про сприяння ініціативам національних меншин, зменшується вплив Змішаних міжурядових комісій на їх правове забезпечення. Питання права, відповідальності, релігійної дискримінації та безпеки держав, що були декларовані в Декларації про принципи співробітництва між Українською РCP та Угорською Республікою, практично залишилися поза увагою Комісії [11, с.183-184].

У той же час опитування експертів Закарпатської області показало, що головні проблеми транскордонного співробітництва полягають не у врегулюванні мовних і освітніх питань етнічних груп, а в більш практичній площині: питаннях візового режиму, перетину кордону та асиметрії регіонального розвитку [12, с.332].

Таким чином, багаторівневий характер транскордонних взаємин ускладнює використання виключно кількісних або якісних методів дослідження. В силу того, що транскордонне співробітництво відбувається одночасно на рівнях загальнодержавного регулювання та міжрегіональної співпраці, найбільш доцільними методами дослідження всього комплексу соціально-економічних і етнонаціональних проблем $є$ комбіновані методи. Оптимальним методом аналізу транскордонного співробітництва на загальнодержавному рівні $\epsilon$ контент-аналіз текстів міжурядових угод i домовленостей. Це метод, який комбінує якісні за походженням джерела інформації зі статистичними засобами їх обробки.

\section{СПИСОК ВИКОРИСТАНИХ ДЖЕРЕЛ}

1. Щерба Г.I. Європейський вибір України та розвиток транскордонного співробітництва як предмет емпіричного соціологічного аналізу [Текст] / Г.І. Щерба // Нова парадигма. Філософія. Політологія. Соціологія : [журнал наукових праць] / Нац. пед. ун-т ім. М. П. Драгоманова, Творче об-ня "Нова парадигма". - Київ, 2008. - Вип. 82. - С. 191-205.

2. Исследование основных тенденций динамики и проблем занятости трудоспособного населения Закарапатья в условиях адаптации экономики области к рыночным отношениям / Кол. авторов под ред. д.э.н., проф. Емца Г.С. / Львовское отделение института экономики АН УССР. Отд. региональных проблем комплексного социально-экономического развития Закарпатской области. - Ужгород, 1991. - 54c. 
3. Рекомендації щодо впровадження нових форм транскордонного співробітництва / Кол. авторів за ред. д.е.н., проф. Мікули Н.А. / НАН України. Ін-т регіональних досліджень. - Львів, 2010. - 150 с.

4. Реутов В.С. Транскордонне співробітництво регіонів України: теоретико-практичні аспекти розвитку / В.С. Реутов // Ефективна економіка. - 2011. [Електронний ресурс]. - Режим доступу: http://www.economy.nayka.com.ua

5. Удод К.С. Методичні підходи до оцінювання кадрового потенціалу банківської системи на рівні регіону / Катерина Сергіївна Удод // Науковий вісник Ужгородського університету. Серія "Економіка". - Випуск 2 (36). 2012. - C. 236-242.

6. Мікула Н. Міжтериторіальне та транскордонне співробітництво: монографія / Надія Мікула. - Львів: ІРД НАН України, 2004. - 395 с.

7. Пелін О.В. Індикатори безпеки $\mathrm{CC}$ в контексті українськорумунсько-молдавських стосунків / О.В. Пелін, О.М. Іваць // УкраїнаРумунія-Молдова: історичні, політичні та культурні аспекти взаємин у контексті сучасних європейських процесів: збірник наукових праць / Буковинський політологічний центр / під загальною редакцією А.M. Круглашова. - Чернівці: Букрек, 2009. - Т.ІІІ. - С.166-176.

8. Декларація про принципи співробітництва між Українською РСР та Угорською Республікою по забезпеченню прав національних меншостей. T.1. - К., 2001. - C. $269-274$.

9. Протокол до Декларації про принципи співробітництва між Українською Радянською Соціалістичною Республікою та Угорською Республікою по забезпеченню прав національних меншостей. [Електронний pecypc]. - Режим доступу: http://ukraine.uapravo.net

10. Постанова Кабінету Міністрів України від 14 травня 1992 р. №238 «Про створення Української частини Змішаної українсько-угорської комісії 3 питань забезпечення прав національних меншин. (Із змінами, внесеними згідно з Постановою КМ № 618 ( $\underline{618-96-\Pi)}$ від 08.06.96 ).

11. Пелін О.В. Трансформація становища українців Угорщини та угорців України у контексті міжурядових домовленостей / Олександр Володимирович Пелін, Адріана Олександрівна Червеняк // Вісник Харківського національного університету імені В.Н. Каразіна. Серія : Соціологічні дослідження сучасного суспільства: методологія, теорія, методи. Вип. 27. - Харків, 2011. - С.181-185.

12. Регіональна політика i транскордонне співробітництво в євроінтеграційній стратегії України: збірник наукових праць за матеріалами міжнародної конференції (м. Ужгород, 24 -25 травня 2007 р.) / Відп. ред. І.В. Артьомов. - Ужгород: Ліра, 2007. - 456 с.

\section{REFERENCES}


1. Shcherba, H. I. (2008). Yevropeys'kyy vybir Ukrayiny ta rozvytok transkordonnoho spivrobitnytstva yak predmet empirychnoho sotsiolohichnoho analizu [The European Choice of Ukraine and the Development of Cross-Border Cooperation as a Subject of Empirical Sociological Analysis]. Nova paradyhma. Filosofiya. Politolohiya. Sotsiolohiya, 82, 191-205.

2. Yemets, G.S. (1991). Issledovaniye osnovnykh tendentsiy dinamiki i problem zanyatosti trudosposobnogo naseleniya Zakarapat'ya $\mathrm{v}$ usloviyakh adaptatsii ekonomiki oblasti k rynochnym otnosheniyam [The study of the main trends in the dynamics and problems of employment of the working-age population of Zakarapatia in the context of adaptation of the regional economy to market relations].Uzhhorod.

3. Mikula, N.A. (Eds.) (2010). Rekomendatsiyi shchodo vprovadzhennya novykh form transkordonnoho spivrobitnytstva [Recommendations on introduction of new forms of cross-border cooperation]. L'viv.

4. Reutov, V.YE. (2011). Transkordonne spivrobitnytstvo rehioniv Ukrayiny: teoretyko-praktychni aspekty rozvytku [Cross-border cooperation of the regions of Ukraine: theoretical and practical aspects of development]. Retrieved from: http://www.economy.nayka.com.ua

5. Udod, K.S. Metodychni pidkhody do otsinyuvannya kadrovoho potentsialu bankivs'koyi systemy na rivni rehionu (2012) [Methodological approaches to the assessment of the personnel potential of the banking system at the level of the region]. Ekonomika, 2 (36), 236-242.

6. Mikula, N. (2004). Mizhterytorial'ne ta transkordonne spivrobitnytstvo [Interterritorial and transborder cooperation]. L'viv: IRD NAN Ukrayiny.

7. Pelin, O.V., \& Ivats', O.M. (2009). Indykatory bezpeky YES v konteksti ukrayins'ko-rumuns'ko-moldavs'kykh stosunkiv [EU Security Indicators in the Context of Ukrainian-Romanian-Moldovan Relations]. Ukrayina-RumuniyaMoldova: istorychni, politychni ta kul'turni aspekty vzayemyn u konteksti suchasnykh yevropeys'kykh protsesiv (Vols.III.), (pp.166-176). Chernivtsi: Bukrek.

8. Deklaratsiya pro pryntsypy spivrobitnytstva mizh Ukrayins'koyu RSR ta Uhors'koyu Respublikoyu po zabezpechennyu prav natsional'nykh menshostey (2001) [Declaration on Principles of Cooperation between the Ukrainian SSR and the Hungarian Republic for the Protection of the Rights of National Minorities]. (Vols.1), (pp.269-274).

9. Protokol do Deklaratsiyi pro pryntsypy spivrobitnytstva mizh Ukrayins'koyu Radyans'koyu Sotsialistychnoyu Respublikoyu ta Uhors'koyu Respublikoyu po zabezpechennyu prav natsional'nykh menshostey [Protocol to the Declaration on the Principles of Cooperation between the Ukrainian Soviet Socialist Republic and the Hungarian Republic for the Protection of the Rights of National Minorities]. Retrieved from: http://ukraine.uapravo.net

10. Postanova Kabinetu Ministriv Ukrayiny «Pro stvorennya Ukrayins'koyi chastyny Zmishanoyi ukrayins'ko-uhors'koyi komisiyi z pytan' zabezpechennya prav natsional'nykh menshyn [The Resolution of the Cabinet of Ministers of 
Ukraine "On the Establishment of the Ukrainian Part of the Mixed UkrainianHungarian Commission on the Protection of the Rights of National Minorities.

11. Pelin, O.V. (2011).Transformatsiya stanovyshcha ukrayintsiv Uhorshchyny ta uhortsiv Ukrayiny u konteksti mizhuryadovykh domovlenostey [Transformation of the situation of Ukrainians of Hungary and Hungarians of Ukraine in the context of intergovernmental agreements]. Sotsiolohichni doslidzhennya suchasnoho suspil'stva: metodolohiya, teoriya, metody, 27, 181185 .

12. Art'omov, I.V. (Eds.). (2007). Rehional'na polityka i transkordonne spivrobitnytstvo $\mathrm{v}$ yevrointehratsiyniy stratehiyi Ukrayiny [Regional policy and cross-border cooperation in the European integration strategy of Ukraine]. Uzhhorod: Lira. 